Copyright ( $) 2020$ University of Bucharest Printed in Romania. All rights reserved

ISSN print: $1224-5984$

ISSN online: $2248-3942$
Rom Biotechnol Lett. 2020; 25(5): 1899-1907

doi: $10.25083 / \mathrm{rbl} / 25.5 / 1899.1907$

Received for publication, November, 30, 2018

Accepted, June, 27, 2020

Original paper

\title{
Characterization of a platform based on dendritic cells for new therapeutic vaccine development
}

\author{
DENISA L. DRAGU ${ }^{1}$, ANA I. NEAGU ${ }^{1}$, LILIA MATEI ${ }^{1}$, CORALIA BLEOTU ${ }^{1}$, \\ SIMONA M. RUTA ${ }^{1,2}$, CARMEN C. DIACONU ${ }^{1, *}$
}

${ }^{1}$ Stefan S. Nicolau Institute of Virology, Bucharest, Romania

${ }^{2}$ Carol Davila University of Medicine and Pharmacy, Bucharest, Romania

\begin{abstract}
Dendritic cells are professional antigen presenting cells involved in uptaking, processing and presenting antigens to naive and memory $\mathrm{T}$ cells. Recently, there has been a growing interest in exploring the therapeutic potential of dendritic cells manipulation. Dendritic cellsbased vaccines represent a promising approach in various types of cancer, infectious diseases or autoimmune disorders. In this regard, the aim of the present research was to characterize a platform based on murine dendritic cells that might serve to the development of new immunotherapeutic strategies in infectious diseases. Our results showed the generation of a dendritic cell population with high purity from murine bone marrow that could be transfected with mRNA, able to maturate and synthetize an important number of cytokines and chemokines. These bone marrow dendritic cells could be further used as a platform for the development of dendritic cell-based vaccines, as well as an in vitro system for the evaluation of DNA or mRNA based vaccines.
\end{abstract}

Keywords Bone marrow-derived dendritic cells, cytokine and chemokine profile, $\mathrm{T}$ cell activation, mRNA based vaccines.

To cite this article: DRAGU DL, NEAGU AI, MATEI L, BLEOTU C, RUTA SM, DIACONU CC. Characterization of a platform based on dendritic cells for new therapeutic vaccine development. Rom Biotechnol Lett. 2020; 25(5): 1899-1907. DOI: $10.25083 / \mathrm{rbl} / 25.5 / 1899.1907$

$\square$ *Corresponding author: CARMEN C. DIACONU, Stefan S. Nicolau Institute of Virology, Cellular and Molecular Pathology Department; 285 Mihai Bravu Avenue, Bucharest 030304, Romania E-mail: ccdiaconu@yahoo.com Tel/Fax: +403215770 


\section{Introduction}

Dendritic cells (DCs) are professional antigen presenting cells (APC) involved in uptaking, processing and presenting antigens to naive and memory $\mathrm{T}$ cells. Described for the first time by Steinman over forty five years ago (STEINMAN \& al [1]), DCs are considered nowadays essential players in the immune responses, linking innate and adaptive immunity (VAN SPRIEL \& al [2]; STEINMAN [3]). Although diverse populations of DCs have been identified (based on surface makers, location and function), they all originate in bone marrow from hematopoietic stem cells (LIU \& al [4]) being the product of the core lympho-myeloid pathway that may generate a spectrum of phenotypes, from lymphoid to myelo-monocytic, that reflect their dominant developmental pathway (COLLIN \& al [5]). DCs circulate through the bloodstream to peripheral organs and tissues where they are in an immature state presenting high endocytic activity, but limited expression of allostimulatory molecules (CD40, CD80 and CD86). After they encounter a foreign antigen, DCs mature and exhibit a higher expression of co-stimulatory molecules, as well as an elevated ability to migrate to the lymph nodes, to present antigens, and to activate T lymphocytes (ZHOU \& al [6]).

Recently, there has been a growing interest in exploring the therapeutic potential of DCs manipulation. DCs-based vaccination represents a promising approach in various types of cancers, autoimmune disorders and infectious diseases (BLOMBERG \& al [7]; VAN WILLIGEN \& al [8]; GOYVAERTS \& al [9]).

Therapeutic vaccination is a promising approach for the HIV infected patients, that might provide an alternative to the present life-long treatment with antiretroviral drugs, avoiding cumulative drug toxicities and the possible emergence of resistant viral strains. Therapeutic vaccines are created in order to restore and re-educate the exhausted cytotoxic $\mathrm{T}$ lymphocyte response to control the viral replication and to eliminate the viral reservoirs. Such vaccines can be based: (a) on autologous DCs transfected ex vivo with HIV antigens or pulsed with heat inactivated autologous virus (GARCIA \& al [10]) or (b) on the in vivo delivery of a specific immunogen, that is captured and processed by DCs, which in turn prime naïve $\mathrm{T}$ cells, restoring a robust cytotoxic response. Although such approaches proved to be safe and immunogenic, both in animal models and in phase I human clinical trials, there is an overall modest and transitory activation of specific antiviral cytotoxic T lymphocytes responses and a minor effect on viral reservoirs (COELHO \& al [11]; LEAL \& al [12]; SNELLER \& al [13]). New therapeutic vaccines are designed by optimizing the antigen selection, the adjuvants and the administration route. Recent candidates are based on mRNAs encoding for mosaic antigens, representative of inter-clade conserved regions, including sub-dominant epitopes, preferentially targeted by CTLs in persons with low level of viremia (MOTHE \& al [14]; GUARDO \& al [15]). Such mRNA-based vaccines offer significant advantages in terms of delivery system, time of action, safety profile, and route of administration (SAHIN \& al [16]; VAN LINT \& al [17]; UDHAYAKUMAR \& al [18]).

In this regard, the aim of the present research was to establish a platform based on murine dendritic cells that might serve to the assessment of new immunotherapeutic strategies in infectious diseases.

\section{Materials and Methods}

\section{Mice}

CD1 mice aged 6-8 weeks were purchased from Charles River Laboratories and housed in pathogen-free conditions at the animal facilities of Stefan S. Nicolau Institute of Virology.

All experimental procedures were conducted with the approval of the Institutional Ethics Committee in accordance with The National Sanitary Veterinary and Food Safety Authority (ANSVSA) guidelines for housing and care of laboratory animals.

\section{Generation of bone marrow-derived dendritic cells (BMDCs)}

Bone marrow derived dendritic cells were isolated from 6-8 weeks old CD1 mice. Briefly, after femur and tibia removal, the soft tissue was removed and the both ends of the bones were cut. Subsequently, bone marrow was flushed with Dulbecco's phosphate-buffered saline (DPBS) and the cells were collected and cultured in two different primary media consisting of Roswell Park Memorial Institute (RPMI) 1640 medium (ThermoFischer Scientific, USA) supplemented with $10 \%$ Fetal Bovine Serum (FBS) (Biochrom, Germany), 1\% penicillin-streptomycin (Biochrom, Germany), and either $20 \mathrm{ng} / \mathrm{mL}$ of murine granulocyte macrophage colony-stimulating factor (GM-CSF) (Stem Cell Technologies, UK) and $50 \mu \mathrm{mol} / \mathrm{L}$ of 2-mercaptoethanol (ThermoFischer Scientific, USA) [first medium (M1)], or murine $20 \mathrm{ng} / \mathrm{mL}$ of GM-CSF, $20 \mathrm{ng} / \mathrm{mL}$ of murine IL-4 (Stem Cell Technologies, UK) and $2 \mathrm{mM}$ of L-glutamine (Biochrom, Germany) [the second medium (M2)]. The cells were incubated in humidified atmosphere at $37^{\circ} \mathrm{C}$ with $5 \% \mathrm{CO}_{2}$ and the media was replaced after 3 days. On day 6 , the loosely adherent and non-adherent cells were harvested and stimulated with TNF- $\alpha$ (Stem Cell Technologies, UK) $(10 \mathrm{ng} / \mathrm{mL})$ for 6 more days or with Lipopolysaccharide (LPS) (Sigma Aldrich, USA) (100 ng/mL) for 72 hours in order to induce DCs maturation. Morphological characterization of isolated cells, immature and mature BMDCs, was performed on a Zeiss Axio Observer.D1 optical inverted microscope at different time points of the experiment. Images were captured with an AxioCam MRm (CCD) camera.

\section{BMDCs phenotypic characterization}

BMDCs phenotypic characterization was assessed on day 6 and after TNF- $\alpha$ and LPS treatment using CD11cBrilliant Violet 421, MHCII (I-A/I-E)-Brilliant Violet 510, CD86- Brilliant Violet 650, and CD80- PE/Cy5, purchased from BioLegend (USA). In this regard, the cells were incubated with the antibodies for 30 minutes at $4{ }^{\circ} \mathrm{C}$ and washed with DPBS. At least 10000 events from each sample were acquired using Beckman Coulter MoFlo 
Astrios EQ instrument and data were analyzed with Kaluza v 1.3 flow cytometry analysis software.

\section{Dendritic Cells electroporation}

BMDCs were nucleoporated using Mouse Dendritic Cell Nucleofector ${ }^{\mathrm{TM}}$ Kit (Lonza, Switzerland) on Nucleofector ${ }^{\mathrm{TM}} 2 \mathrm{~b}$ Device (Lonza, Switzerland) according to manufacturer protocol, with a mRNA (TriLink Technologies, US) that encodes for HIV gag genes, with modifications of 5-Methyl-C (5MeC) and Pseudo-U (PSU), kindly provided by Joeri Aerts, Vrije Universiteit, Brussels, Belgium. Thus, $2.5 \times 10^{5}$ immature DCs were collected on day 6, washed with DPBS and re-suspended in $100 \mu \mathrm{L}$ Nucleofector Solution per sample. The cell suspensions were mixed with $2.5 \mu \mathrm{g}$ gag mRNA or pmaxGFP ${ }^{\mathrm{TM}}$ Vector (positive control), transferred into certified cuvette and nucleoporated with the program Y-001 optimized for immature dendritic cells nucleofection. After nucleoporation, DCs were transferred in a 48 well plate, re-suspended into pre-warmed culture medium, and incubated for 24 hours at $37^{\circ} \mathrm{C}$ and $5 \% \mathrm{CO}_{2}$. Mock BMDCs, nucleoporated following the same protocol described above, were used as negative control.

To evaluate transfection efficiency, KC57-FITC (Beckman Coulter, USA) antibody for intracellular staining of Gag was used. In this regard, gag mRNA transfected cells were fixed and permeabilized with Cytofix/Cytoperm kit (BD Biosciences, USA) according to manufacturer protocol. At least 10000 events from each sample were acquired using Beckman Coulter MoFlo Astrios EQ instrument and data were analyzed with Kaluza v 1.3 flow cytometry analysis software.

The viability of nucleoporated BMDCs was assessed by 7-Aminoactinomycin D (Biolegend, USA) (7-AAD) according to the kit protocol. The samples were analyzed within 24 hours after staining and 10000 events were collected per sample using Beckman Coulter MoFlo Astrios EQ instrument. Acquired data were analyzed with Kaluza v1.3 flow cytometry analysis software.

\section{Quantitative Real-Time RT-PCR analysis of cytokines mRNA}

Total RNA was isolated using Quick-RNA ${ }^{\text {TMMiniprep }}$ Kit (Zymo Research, USA) according to the manufacturer recommendations. The quantity and purity of extracted RNA were determined using Eppendorf BioPhotometer plus (Eppendorf, Austria). The cDNA synthesis was carried out using High Capacity cDNA Reverse Transcription kit (ThermoFischer Scientific, USA) and the reaction was performed on BioRad DNA ENGINE Dyad thermocycler. For each reaction $2 \mu \mathrm{g}$ of total RNA have been used. Quantitative real-time PCR was performed on StepOne Plus Real-Time PCR System (ThermoFischer Scientific, USA) platform. The IL-1 $\beta$, IL-6, TNF- $\alpha$ mRNA and GAPDH (as endogenous control) level of expression was quantified using Universal SYBR Green Master (Rox) (ThermoFischer Scientific, USA) and gene-specific primers: mIL-6 (Fw: CAACGATGATGCACTTGCAGA, R: TGGAAATTGGGGTAGGAAGGAC), m T NF- $\alpha$
(Fw: TTCTATGGCCCAGACCCTCA,

R: GTGGTTTGCTACGACGTGGG), mIL-1 $\beta$

(Fw: TGCCACCTTTTGACAGTGATG,

R: AAGGTCCACGGGAAAGACAC), and mGAPDH (Fw: GGGTCCCAGAGGTTCATC,

R: ATCCGTTCACACCGACCTTC). Each experiment was performed three times. The relative mRNA expression was calculated as "fold change" (RQ): $2^{-\Delta \Delta C t}$ using StepOne Software v2.3.

\section{Cytokine and chemokine analysis}

The presence of cytokines and chemokine in the supernatants, at 24 hours after electroporation, was determined using the Proteome Profiler Mouse Cytokine Array (R\&D Systems, USA) that can detect the relative expression levels of 40 mouse cytokines and chemokines (CXCL13/BLC, C5a, G-CSG, GM-CSF, CCL1/I-309, CC111/Eotaxin, ICAM-1, IFN- $\gamma$, IL-1 $\alpha / \mathrm{IL}-1 \mathrm{~F} 1, \mathrm{IL}-1 \beta / \mathrm{IL}-1 \mathrm{~F} 2$, IL-1ra/IL-1F3, IL-2, IL-3, IL-4, IL-5, IL-6, IL-7, IL-10, IL-12p70, IL-13, IL-16, IL-17, IL-23, IL-27, CXCL10/IP-10, CXCL11/I-TAC, CXCL1/KC, M-CSF, CCL2/JE/MCP-1, CCL12/MCP-5, CXCL9/MIG, CCL3/MIP-1 $\alpha$, CCL4/MIP-1 $\beta$, CXCL2/MIP-2, CCL5/RANTES, CXCL12/SDF-1, CCL17/TARC, TIMP-1, TNF- $\alpha$, TREM-1). In summary, $600 \mu \mathrm{L}$ of sample supernatants and $15 \mu \mathrm{L}$ of Mouse Cytokine Array Panel A Detection Antibody Cocktail were incubated at room temperature for one hour. The sample/antibody mixtures were put together with the membranes overnight on a rocking platform shaker at $2-8^{\circ} \mathrm{C}$. After incubation, the membranes were washed and Streptavidin-HRP and chemiluminescent detection reagents were added. Image acquisition was performed with the MicroChemi 4.2 instrument (DNR Bio Imaging Systems). The cytokine profile assessment was realized with ImageJ software by measuring the signal intensity of each spot.

7. Statistical analysis of the data was performed using GraphPad Prism 6.01 software and the data were presented by mean \pm standard deviation. The significance between two groups was determined by ANOVA test; $p<0.05$ was considered to indicate a statistically significant difference.

\section{Results and Discussion}

\section{BMDCs morphological and phenotypical characterization}

Due to the low frequency of DCs in the circulation, clinical applications and even research on primary human DCs are impaired. Though, in the last decades numerous of studies have been conducted to develop methods to generate DCs in vitro from various cellular sources, including peripheral blood, bone marrow or umbilical cord blood (BALAN \& al [19]; BOL \& al [20]), and pluripotent stem cells (SENJU \& al [21]; SENJU \& al [22]). In order to establish an efficient method to generate murine BMDCs, initially, two protocols that used different culture media (M1 and M2 detailed in Materials and Methods section) were tested. For the morphological characterization of BMDCs, the primary cultures were observed under the microscope at different time points. Morphological 
appearances of cells during differentiation varied from small size and spherical shape on day 0 , to a more heterogeneous morphology with elongated and spherical cells that started to form colonies on day 3. Six days after culture initiation, adherent cells that exhibited macrophage specific features and numerous semi-adherent and floating cells were observed. Changes in cellular morphology were also verified at 72 hours after LPS treatment and at 6 days after TNF- $\alpha$ stimulation (Fig. 1A and Fig. 2A).
The addition of maturation stimuli, LPS $(100 \mathrm{ng} / \mathrm{mL})$ or TNF- $\alpha(10 \mathrm{ng} / \mathrm{mL})$, induced an increase of the cell population with numerous dendritic cytoplasmic extensions. DCs surface expression of CD11c, co-stimulatory molecules CD80 and CD86 and MHCII were assessed by flow cytometry analysis (Fig. 1B and Fig. 2B). The DCs marker CD11c was expressed by $89.03 \%$ DCs grown in medium supplemented with GM-CSF only and by $71.55 \%$ DCs cultivated in the presence of GM-CSF and IL-4.

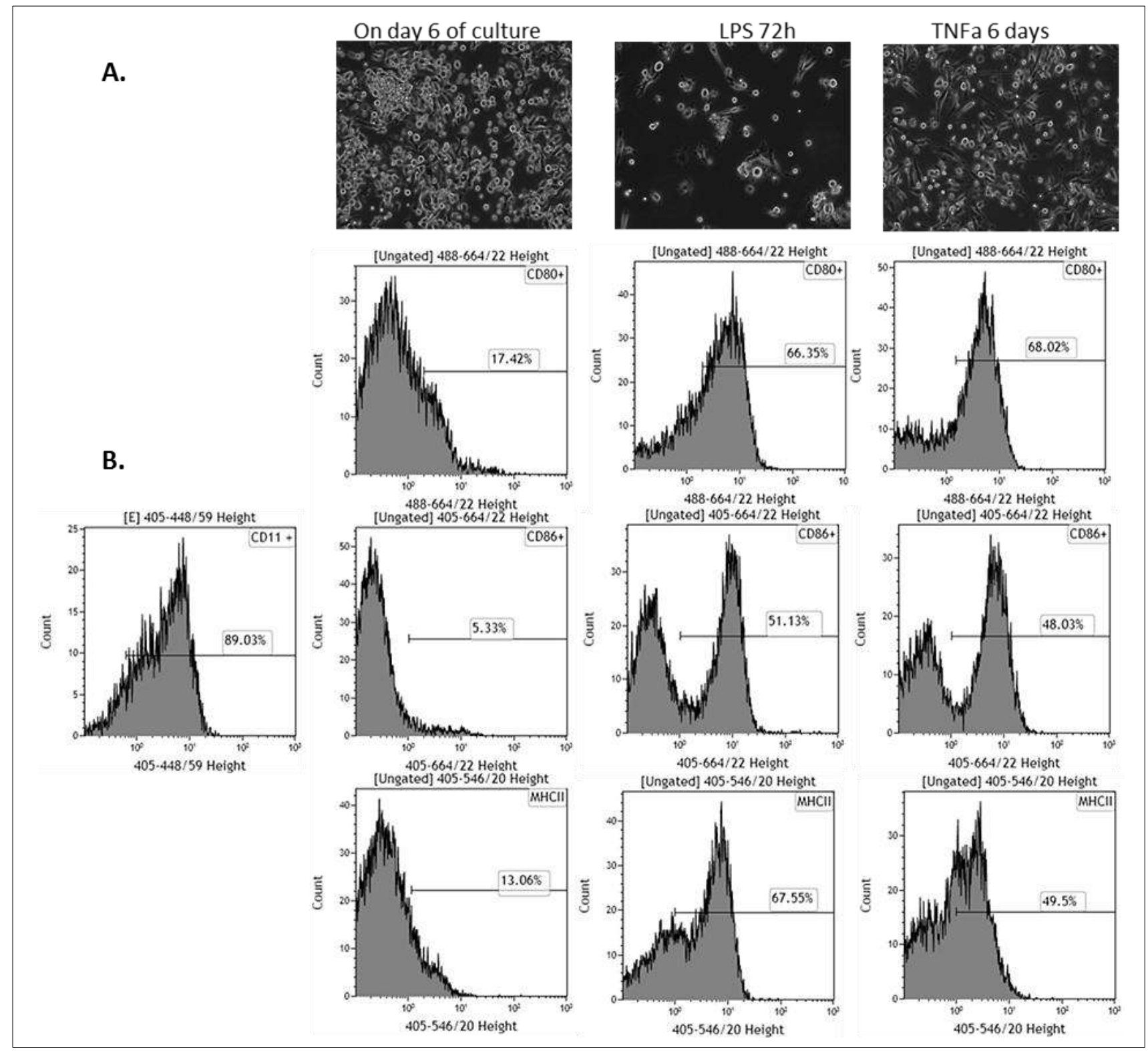

Figure 1. Morphology and phenotype of murine BMDCs, cultivated in M1 medium, before and after stimulation with LPS or TNF- $\alpha$. A. Morphological appearances of immature and mature dendritic cells evaluated by inverted microscopy (200x); B. Flow cytometry histograms of BMDCs at 6 days after initiation, $72 \mathrm{~h}$ after LPS treatment and 6 days TNF- $\alpha$ stimulation.

The immature BMDCs expressed low levels of CD80 and CD86: $17.42 \%$ CD80 and 5.33\% CD86 for cells grown in M1 medium, and, respectively, $22.10 \%$ CD80 and $12.49 \%$ CD86 for cells grown in M2 medium. MHCII expression on the surface of immature DCs varied from
$13.06 \%$ in $\mathrm{M} 1$ to $30.71 \%$ in $\mathrm{M} 2$ cultivated cells. An increased expression of MHCII and co-stimulatory markers, CD86 and CD80 was observed in the presence of maturation factors, regardless of the primary medium used. 


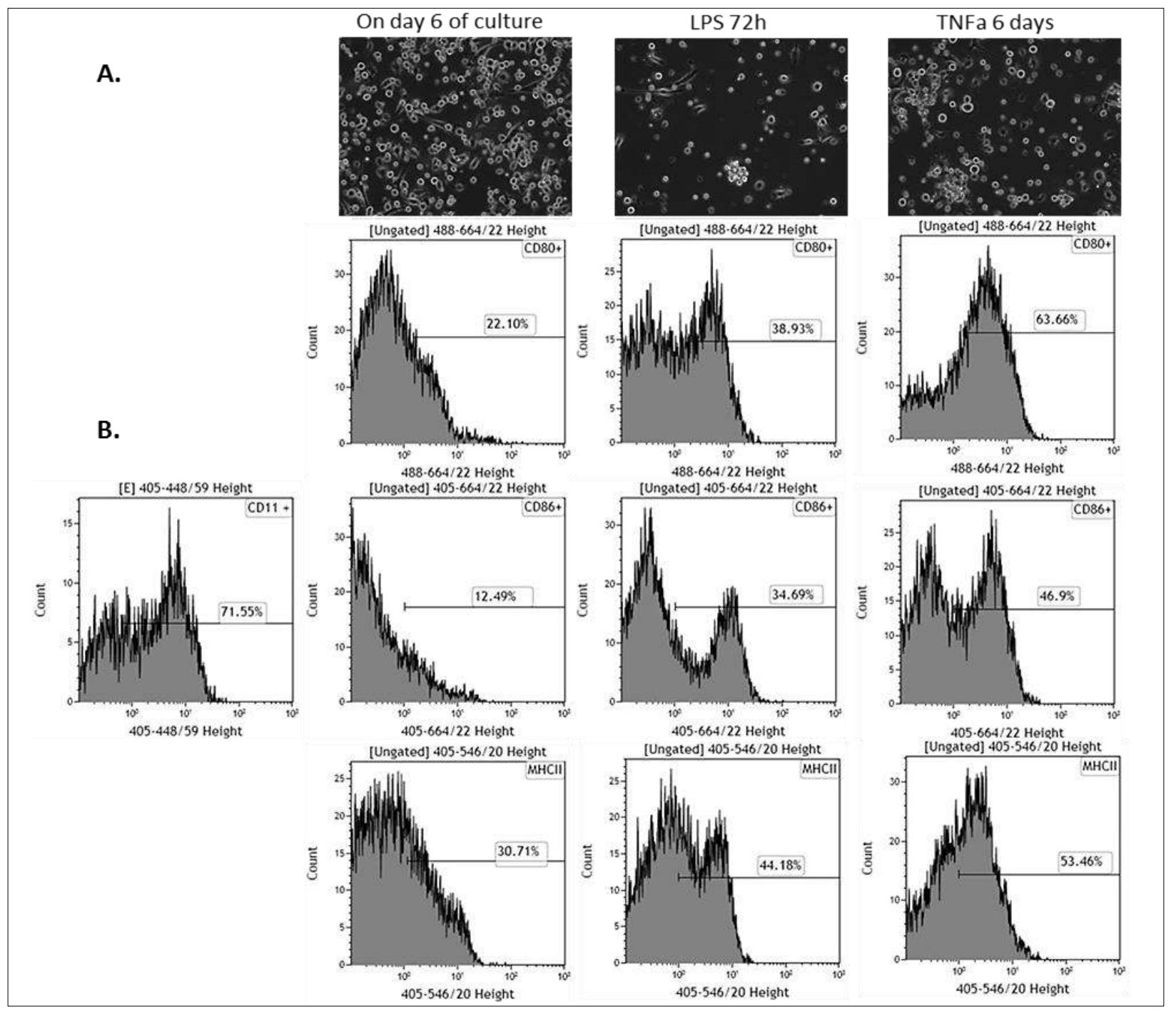

Figure 2. Morphology and phenotype of murine BMDCs, cultivated in M2 medium, before and after stimulation with LPS and TNF- $\alpha$. A. Morphological appearances of immature and mature dendritic cells evaluated by inverted microscopy (200x); B. Flow cytometry histograms of BMDCs at 6 days after initiation, 72 hours after LPS treatment and 6 days TNF- $\alpha$ stimulation.

\section{In vitro nucleoporation of BMDCs}

In order to transfect the immature BMDCs without altering their immunological functionality, the cells were nucleoporated with $2.5 \mu \mathrm{g}$ gag mRNA or pmaxGFP ${ }^{\mathrm{TM}}$ Vector, using Nucleofector ${ }^{\mathrm{TM}}$ 2b Device. The nucleoporation efficiency was assessed by fluorescent microscopy and flow-cytometry. Flow cytometric analysis indicated that 24 hours after nucleoporation $59.09 \%$ of CD11 $\mathrm{c}^{+}$cells were positive for gag expression (Fig. 3). The viability assessment showed that more than $90 \%$ of mock and gag mRNA expressing cells were viable.
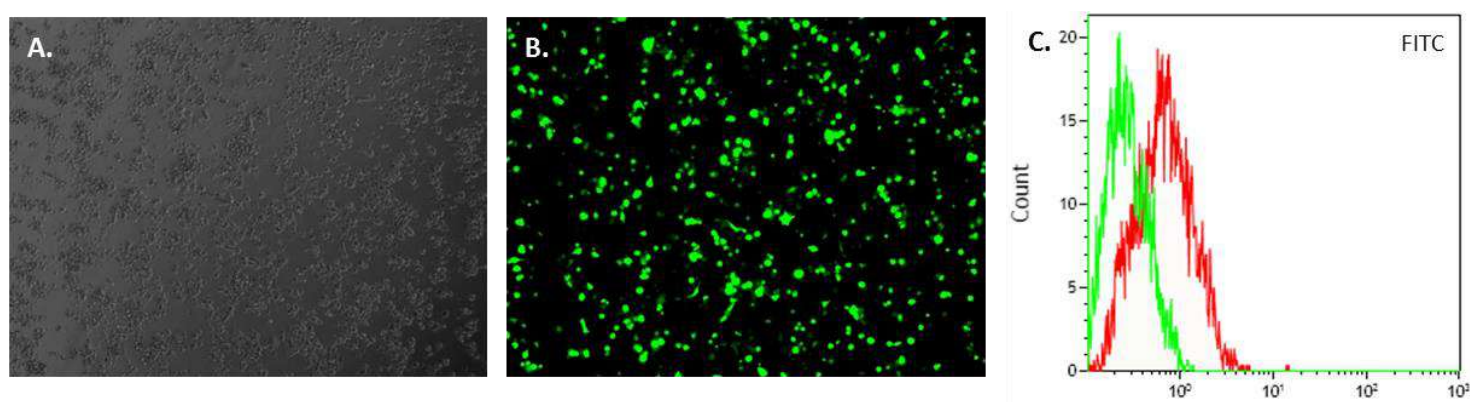

Figure 3. Nucleoporated murine BMDCs. A. pmaxGFP ${ }^{\mathrm{TM}}$ nucleoporated cells (phase contrast, 100x); B. Efficiency of nucleoporation in positive control (pmaxGFP ${ }^{\mathrm{TM}}$ nucleoporated cells) at 24 hours after nucleoporation (fluorescence, 100x); C. Histogram representing gag mRNA positive cells (red) compared to mock cells (green) quantified by flow cytometry using KC57-FITC antibody. 


\section{BMDCs phenotype after nucleoporation}

DCs maturation is associated with increases in MHC and co-stimulatory molecules expression levels, with modifications in the pattern of chemokine receptor expression and, also, with enhanced secretion of inflammatory cytokines and chemokines. In vivo, these phenotypic changes are associated with maturation, prompting DCs migration to the lymph nodes and antigen presentation to naïve T cells (MICHIELS \& al [23]). In our experiments, the maturation status of the nucleoporated BMDCs was assessed by flow cytometric analysis of maturation markers on cells surface (Fig. 4). Nucleoporated cells, cultivated without any maturation stimuli displayed a slight increase in the expression of CD80 and CD86 co-stimulatory molecules, leading to a ,semi-mature" phenotype. Consistent with our findings, previous studies showed that loading of immature DCs with different antigens induces a minor maturation, additional stimuli being required to achieve full maturation (BAERT \& al [24]). In human DCs, mRNA transfection by lipofection induces maturation more efficiently than electroporation (MELHEM \& al [25]; CEPPI \& al [26]; KARIKO \& al [27]). Nevertheless, electroporation itself, irrespective of mRNA presence, does not induce BMDC's maturation and does not affect the cells' immunostimulatory capacity (VAN MEIRVENNE $\&$ al [28]).
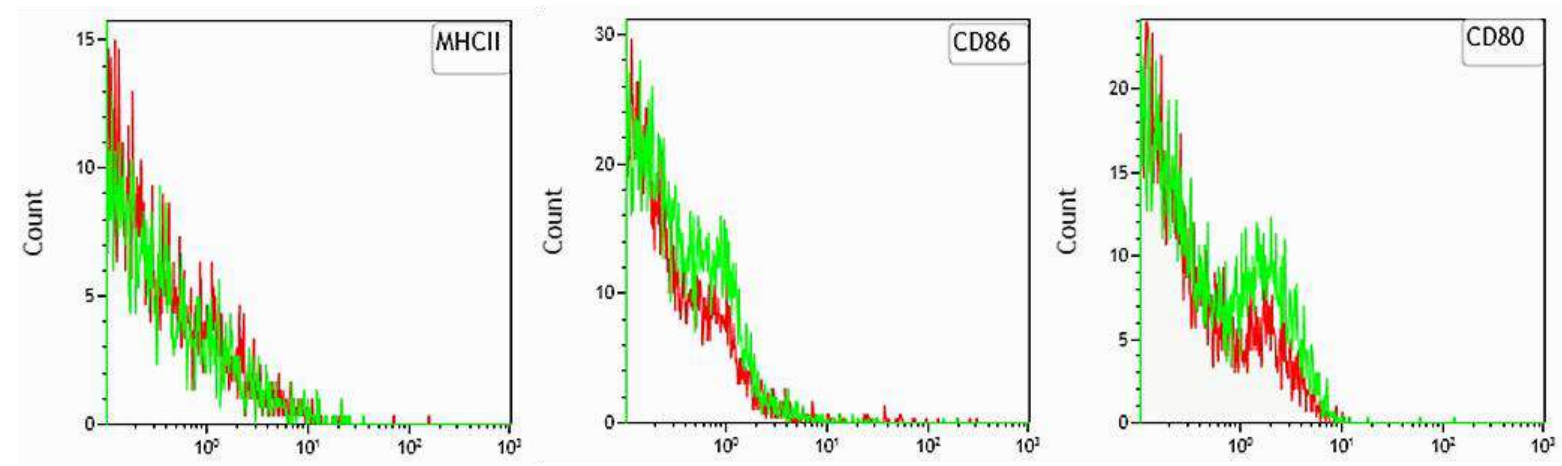

Figure 4. Flow cytometric analysis of maturation markers (MHCII, CD86, and CD80) on BMDCs 24 hours after nucleoporation evaluated by flow cytometry using MHCII (I-A/I-E)-Brilliant Violet 510, CD86- Brilliant Violet 650, and CD80- PE/Cy5.

\section{Characterization of BMDCs functions after electroporation}

Since cytokine secretion is a strong indicator of mature DCs function, we determined the expression of different cytokines and chemokines, 24 hours post-electroporation.

IL-1及, IL-6, and TNF- $\alpha$ genes expression. In order to analyze the activation of nucleoporated cells, the mRNA levels of IL-1 $\beta$, IL- 6 , and TNF- $\alpha$ genes were evaluated.

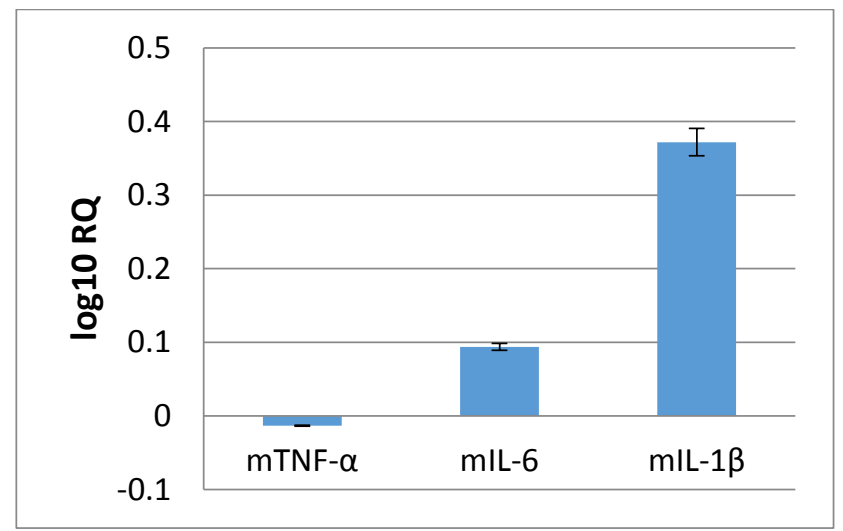

Figure 5. The mRNA expression levels of IL-1 $\beta$, IL-6, and TNF- $\alpha$ genes in BMDCs nucleoporated cells compared to mock cells.

As presented in Figure 5, gag mRNA nucleoporated BMDCs displayed an increased expression of pro-inflammatory cytokines IL-1 $\beta$ and IL-6, but a decreased TNF- $\alpha$ mRNA expression.

Cytokine protein profile assessment. A proteome profiler cytokine array was used to assess the profile of cytokines synthetized by DCs after nucleoporation with gag HIV mRNA. Our results show that out of 40 mouse cytokines and chemokines assessed, 6 have significantly increased levels in the supernatant of the gag mRNA nucleoporated cells: CCL3/MIP-1 $\alpha$, CCL4/MIP-1 $\beta$, CXCL2/ MIP-2, CCL17/TARC, ICAM-1 (CD54), IL-1 $\alpha /$ IL-1F1. Higher levels of IL-12p70, IFN- $\gamma$, IL-1 $\beta / \mathrm{IL}-1 \mathrm{~F} 2$, IL-16, and IL-17, as well as modest increases in the IL-5 and IL-7 levels, were also observed, but did not reach statistical significance (Fig. 6).

In vivo, CCL3/MIP-1 $\alpha$ and CCL4/MIP-1 $\beta$ are secreted early by activated DCs, being involved in the recruitment of innate immune cells (JING \& al [29]; SCHINNERLING \& al [30]). These chemokines bind the CCR5 receptor and induce direct chemotaxis to the site of microbial invasion and inflammation. In murine models, the macrophage inflammatory proteins MIP-1 $\alpha$ and MIP-1 $\beta$ are associated with the secretion of IFN- $\gamma$, a specific Th1 cytokine by polyclonally activated NK and T cells (DORNER \& al [31]).

The activation of BMDCs nucleoporated cells is also endorsed by the elevated levels of CD54 and TARC (thymus and activation regulated chemokine TARC/CCL17). CD54/ICAM-1 (Intercellular Adhesion Molecule 1) is 
a well-known phenotypic marker of APC, involved in the direct interaction with $\mathrm{T}$ cells, as well as in the priming of naïve T cells (SHEIKH \& al [32]), while TARC/CCL17 is involved in Th1 and Th2 recruitment (HAYASHIDA \& al [33]; ALFERINK \& al [34]).

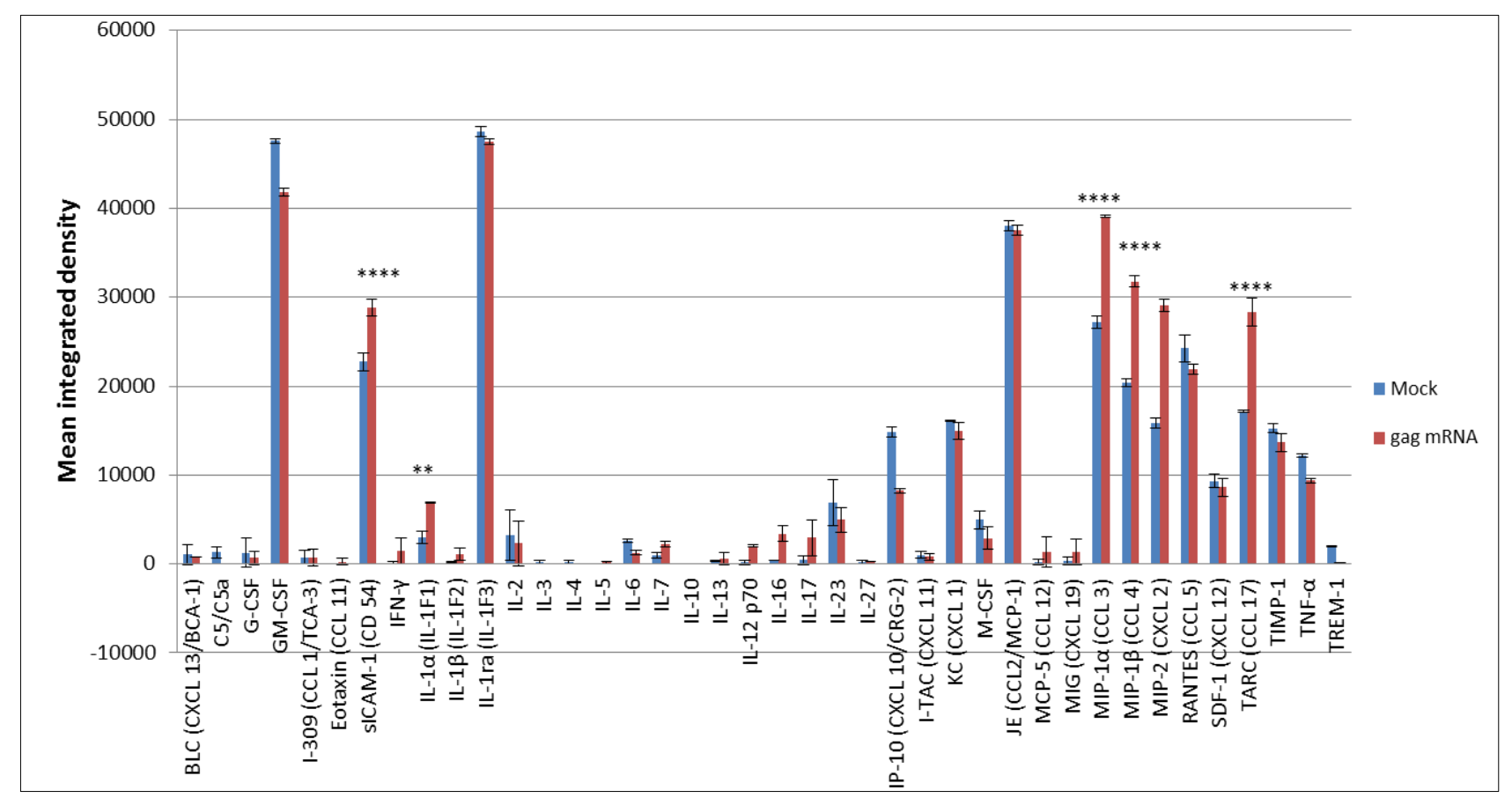

Figure 6. Cytokine and chemokine expression levels in BMDCs nucleoporated with gag mRNA compared to mock cells determined using the Proteome Profiler Mouse Cytokine Array; **P $<0.001$; ****P $<0.00001$.

\section{Conclusions}

This study reports the generation of a high purity population of dendritic cells (over $70 \%$ expressing CD11c+ marker), from the bone marrow of 6-8 weeks old CD1 mice, using either GM-CSF alone or a combination of GMCSF and IL-4. These isolated dendritic cells are maturated and activated after transfection with an HIV gag specific mRNA, being able to synthetize an important number of cytokines and chemokines. As such, these murine bone marrow-derived dendritic cells can be further used as a platform for the development of DCs-based vaccines, as well as an in vitro system for the evaluation of DNA or mRNA based vaccines candidates.

Comparative genomics studies of human and mouse immune cell subsets have revealed conserved profiles (ROBBINS \& al [35]; CROZAT \& al [36]) despite the differences in the immune system development, surface phenotypes and functions (MESTAS \& al [37]). As such, in vitro studies on murine DCs can facilitate a rapid translation to humans, allowing an efficient evaluation of new immunotherapeutic strategies.

\section{Acknowledgments}

This work was supported by a grant of the Romanian National Authority for Scientific Research and Innovation CCDI- UEFISCDI PN CD III- "Programul 3 - Cooperare europeana si internationala" HIVERA, project number4/2016 HIVNANOVA.
We thank Joeri Aerts for kindly providing the mRNA encoding HIV gag genes.

\section{Conflict of interest}

Equally contributing authors: DENISA L. DRAGU, ANA I. NEAGU and LILIA MATEI.

\section{References}

1. R.M. STEINMAN, Z.A. COHN. Identification of a novel cell type in peripheral lymphoid organs of mice. I. Morphology, quantitation, tissue distribution. J Exp Med, 137 (5), 1142-1162 (1973).

2. A.B. VAN SPRIEL, E.C. DE JONG. Dendritic cell science: more than 40 years of history. J Leukoc Biol, 93 (1), 33-38 (2013).

3. R.M. STEINMAN. Linking innate to adaptive immunity through dendritic cells. Novartis Found Symp, 279, 101-109; discussion 109-113, 216-109 (2006).

4. K. LIU, M.C. NUSSENZWEIG. Origin and development of dendritic cells. Immunol Rev, 234 (1), 45-54 (2010).

5. M. COLlin, V. Bigley. Human dendritic cell subsets: an update. Immunology, 154 (1), 3-20 (2018).

6. Q. ZHOU, Y. ZHANG, M. ZHAO, X. WANG, C. MA, X. JIANG, T. WU, D. WANG, L. ZHAN. Mature dendritic cell derived from cryopreserved immature dendritic cell shows impaired homing ability and reduced anti-viral therapeutic effects. Sci Rep, 6, 39071 (2016). 
7. O.S. BLOMBERG, L. SPAGNUOLO, K.E. DE VISSER. Immune regulation of metastasis: mechanistic insights and therapeutic opportunities. Dis Model Mech, 11 (10), (2018).

8. W.W. VAN WILLIGEN, M. BLOEMENDAL, W.R. GERRITSEN, G. SCHREIBELT, I.J.M. DE VRIES, K.F. BOL. Dendritic Cell Cancer Therapy: Vaccinating the Right Patient at the Right Time. Front Immunol, 9, 2265 (2018).

9. C. GOYVAERTS, K. BRECKPOT. The Journey of in vivo Virus Engineered Dendritic Cells From Bench to Bedside: A Bumpy Road. Front Immunol, 9, 2052 (2018).

10. F. GARCIA, N. CLIMENT, A.C. GUARDO, C. GIL, A. LEON, B. AUTRAN, J.D. LIFSON, J. MARTINEZ-PICADO, J. DALMAU, B. CLOTET, J.M. GATELL, M. PLANA, T. GALLART, D.M.O.S. GROUP. A dendritic cell-based vaccine elicits T cell responses associated with control of HIV-1 replication. Sci Transl Med, 5 (166), 166ra162 (2013).

11. A.V. COELHO, R.R. DE MOURA, A.J. KAMADA, R.C. DA SILVA, R.L. GUIMARAES, L.A. BRANDAO, L.C. DE ALENCAR, S. CROVELLA. Dendritic CellBased Immunotherapies to Fight HIV: How Far from a Success Story? A Systematic Review and MetaAnalysis. Int J Mol Sci, 17 (12), (2016).

12. L. LEAL, A.C. GUARDO, S. MORON-LOPEZ, M. SALGADO, B. MOTHE, C. HEIRMAN, P. PANNUS, G. VANHAM, H.J. VAN DEN HAM, R. GRUTERS, A. ANDEWEG, S. VAN MEIRVENNE, J. PICH, J.A. ARNAIZ, J.M. GATELL，C. BRANDER, K. THIELEMANS, J. MARTINEZ-PICADO, M. PLANA, F. GARCIA, H.C. I. Phase I clinical trial of an intranodally administered mRNA-based therapeutic vaccine against HIV-1 infection. AIDS, 32 (17), 25332545 (2018).

13. M.C. SNELLER, J.S. JUSTEMENT, K.R. GITTENS, M.E. PETRONE, K.E. CLARRIDGE, M.A. PROSCHAN, R. KWAN, V. SHI, J. BLAZKOVA, E.W. REFSLAND, D.E. MORRIS, K.W. COHEN, M.J. MCELRATH, R. XU, M.A. EGAN, J.H. ELDRIDGE, E. BENKO, C. KOVACS, S. MOIR, T.W. CHUN, A.S. FAUCI. A randomized controlled safety/efficacy trial of therapeutic vaccination in HIVinfected individuals who initiated antiretroviral therapy early in infection. Sci Transl Med, 9 (419), (2017).

14. B. MOTHE, A. LLANO, J. IBARRONDO, M. DANIELS, C. MIRANDA, J. ZAMARRENO, V. BACH, R. ZUNIGA, S. PEREZ-ALVAREZ, C.T. BERGER, M.C. PUERTAS, J. MARTINEZ-PICADO, M. ROLLAND, M. FARFAN, J.J. SZINGER, W.H. HILDEBRAND, O.O. YANG, V. SANCHEZMERINO, C.J. BRUMME, Z.L. BRUMME, D. HECKERMAN, T.M. ALLEN, J.I. MULLINS, G. GOMEZ, P.J. GOULDER, B.D. WALKER, J.M. GATELL, B. CLOTET, B.T. KORBER, J. SANCHEZ, C. BRANDER. Definition of the viral targets of protective HIV-1-specific T cell responses. J Transl Med, 9, 208 (2011).
15. A.C. GUARDO, P.T. JOE, L. MIRALlES, M.E. BARGALLO, B. MOTHE, A. KRASNIQI, C. HEIRMAN, F. GARCIA, K. THIELEMANS, C. BRANDER, J.L. AERTS, M. PLANA, H.C. I. Preclinical evaluation of an mRNA HIV vaccine combining rationally selected antigenic sequences and adjuvant signals (HTI-TriMix). AIDS, 31 (3), 321-332 (2017).

16. U. SAHIN, K. KARIKO, O. TURECI. mRNA-based therapeutics--developing a new class of drugs. Nat Rev Drug Discov, 13 (10), 759-780 (2014).

17. S. VAN LINT, C. HEIRMAN, K. THIELEMANS, K. BRECKPOT. mRNA: From a chemical blueprint for protein production to an off-the-shelf therapeutic. Hum Vaccin Immunother, 9 (2), 265-274 (2013).

18. V.K. UDHAYAKUMAR, A. DE BEUCKELAER, J. MCCAFFREY, C.M. MCCRUDDEN, J.L. KIRSCHMAN, D. VANOVER, L. VAN HOECKE, K. ROOSE, K. DESWARTE, B.G. DE GEEST, S. LIENENKLAUS, P.J. SANTANGELO, J. GROOTEN, H.O. MCCARTHY, S. DE KOKER. Arginine-Rich PeptideBased mRNA Nanocomplexes Efficiently Instigate Cytotoxic $\mathrm{T}$ Cell Immunity Dependent on the Amphipathic Organization of the Peptide. Adv Healthc Mater, 6 (13), (2017).

19. S. BALAN, V.P. KALE, L.S. LIMAYE. A simple twostep culture system for the large-scale generation of mature and functional dendritic cells from umbilical cord blood CD34+ cells. Transfusion, 49 (10), 21092121 (2009).

20. K.F. BOL, J. TEL, I.J. DE VRIES, C.G. FIGDOR. Naturally circulating dendritic cells to vaccinate cancer patients. Oncoimmunology, 2 (3), e23431 (2013).

21. S. SENJU, Y. MATSUNAGA, S. FUKUSHIMA, S. HIRATA, Y. MOTOMURA, D. FUKUMA, H. MATSUYOSHI, Y. NISHIMURA. Immunotherapy with pluripotent stem cell-derived dendritic cells. Semin Immunopathol, 33 (6), 603-612 (2011).

22. S. SENJU, S. HIRATA, Y. MOTOMURA, D. FUKUMA, Y. MATSUNAGA, S. FUKUSHIMA, H. MATSUYOSHI, Y. NISHIMURA. Pluripotent stem cells as source of dendritic cells for immune therapy. Int $J$ Hematol, 91 (3), 392-400 (2010).

23. A. MICHIELS, S. TUYAERTS, A. BONEHILL, J. CORTHALS, K. BRECKPOT, C. HEIRMAN, S. VAN MEIRVENNE, M. DULLAERS, S. ALLARD, F. BRASSEUR, P. VAN DER BRUGGEN, K. THIELEMANS. Electroporation of immature and mature dendritic cells: implications for dendritic cellbased vaccines. Gene Ther, 12 (9), 772-782 (2005).

24. T. BAERT, A.D. GARG, E. VINDEVOGEL, V.A.N.H. A, G. VERBIST, P. AGOSTINIS, I. VERGOTE, A.N. COOSEMANS. In Vitro Generation of Murine Dendritic Cells for Cancer Immunotherapy: An Optimized Protocol. Anticancer Res, 36 (11), 57935801 (2016).

25. N.M. MELHEM, X.D. LIU, D. BOCZKOWSKI, E. GILBOA, S.M. BARRATT-BOYES. Robust CD4+ 
and CD8+ $\mathrm{T}$ cell responses to SIV using mRNAtransfected DC expressing autologous viral Ag. Eur J Immunol, 37 (8), 2164-2173 (2007).

26. M. CEPPI, N. RUGGLI, V. TACHE, H. GERBER, K.C. MCCULLOUGH, A. SUMMERFIELD. Doublestranded secondary structures on mRNA induce type I interferon (IFN alpha/beta) production and maturation of mRNA-transfected monocyte-derived dendritic cells. J Gene Med, 7 (4), 452-465 (2005).

27. K. KARIKO, H. NI, J. CAPODICI, M. LAMPHIER, D. WEISSMAN. mRNA is an endogenous ligand for Toll-like receptor 3. J Biol Chem, 279 (13), 1254212550 (2004).

28. S. VAN MEIRVENNE, L. STRAETMAN, C. HEIRMAN, M. DULLAERS, C. DE GREEF, V. VAN TENDELOO, K. THIELEMANS. Efficient genetic modification of murine dendritic cells by electroporation with mRNA. Cancer Gene Ther, 9 (9), $787-$ 797 (2002).

29. H. JING, E. VASSILIOU, D. GANEA. Prostaglandin E2 inhibits production of the inflammatory chemokines CCL3 and CCL4 in dendritic cells. J Leukoc Biol, 74 (5), 868-879 (2003).

30. K. SCHINNERLING, P. GARCIA-GONZALEZ, J.C. AGUILLON. Gene Expression Profiling of Human Monocyte-derived Dendritic Cells - Searching for Molecular Regulators of Tolerogenicity. Front Immunol, 6, 528 (2015).

31. B.G. DORNER, A. SCHEFFOLD, M.S. ROLPH, M.B. HUSER, S.H. KAUFMANN, A. RADBRUCH, I.E. FLESCH, R.A. KROCZEK. MIP-1alpha, MIP-1beta, RANTES, and ATAC/lymphotactin function together with IFN-gamma as type 1 cytokines. Proc Natl Acad Sci U S A, 99 (9), 6181-6186 (2002).

32. N.A. SHEIKH, L.A. JONES. CD54 is a surrogate marker of antigen presenting cell activation. Cancer Immunol Immunother, 57 (9), 1381-1390 (2008).

33. S. HAYASHIDA, H. UCHI, Y. MOROI, M. FURUE. Decrease in circulating Th17 cells correlates with increased levels of CCL17, IgE and eosinophils in atopic dermatitis. J Dermatol Sci, 61 (3), 180-186 (2011).

34. J. ALFERINK, I. LIEBERAM, W. REINDL, A. BEHRENS, S. WEISS, N. HUSER, K. GERAUER, R. ROSS, A.B. RESKE-KUNZ, P. AHMAD-NEJAD, H. WAGNER, I. FORSTER. Compartmentalized production of CCL17 in vivo: strong inducibility in peripheral dendritic cells contrasts selective absence from the spleen. J Exp Med, 197 (5), 585-599 (2003).

35. S.H. ROBBINS, T. WALZER, D. DEMBELE, C. THIBAULT, A. DEFAYS, G. BESSOU, H. XU, E. VIVIER, M. SELLARS, P. PIERRE, F.R. SHARP, S. CHAN, P. KASTNER, M. DALOD. Novel insights into the relationships between dendritic cell subsets in human and mouse revealed by genome-wide expression profiling. Genome Biol, 9 (1), R17 (2008).

36. K. CROZAT, R. GUITON, M. GUILliAMS, S. HENRI, T. BARANEK, I. SCHWARTZ-CORNIL, B. MALISSEN, M. DALOD. Comparative genomics as a tool to reveal functional equivalences between human and mouse dendritic cell subsets. Immunol Rev, 234 (1), 177-198 (2010).

37. J. MESTAS, C.C. HUGHES. Of mice and not men: differences between mouse and human immunology. J Immunol, 172 (5), 2731-2738 (2004). 